\title{
Explosive fragmentation and eruption of kimberlite, insights from the Victor Northwest pipe (Canada)
}

\author{
Bram I. van Straaten ${ }^{1, *}$, M.G. Kopylova ${ }^{1}$, J.K. Russell ${ }^{1}$, \\ K.J. Webb ${ }^{2,3}$ and B.H. Scott Smith ${ }^{4,1}$ \\ ${ }^{1}$ Department of Earth and Ocean Sciences, University of British Columbia, Canada $;{ }^{2}$ De Beers \\ Canada Inc., Exploration Division; ${ }^{3}$ Now at: Mineral Services Canada Inc.; ${ }^{4}$ Scott-Smith \\ PetrologyInc., Canada. ${ }^{*}$ bvanstraaten@eos.ubc.ca / phone: +1 604-8220671
}

\section{INTRODUCTION}

The Victor kimberlite is located in the James Bay Lowland of Northern Ontario. This Middle-Late Jurassic volcanic complex comprises several adjacent and cross-cutting steep-sided $\left(\sim 70^{\circ}\right)$ kimberlite pipes that occur in a $\sim 275 \mathrm{~m}$ thick Palaeozoic sedimentary succession, unconformably overlying granitoid basement. This contribution presents the eruption history of Victor Northwest (VNW; diameter $\sim 300 \mathrm{~m}$ ), one of the early-formed pipes in the kimberlite complex. The emplacement of this body is interpreted to have involved variably explosive eruptions, ranging from low energy fire fountaining to highly explosive phreatomagmatic events.

\section{INTERPRETED ERUPTIVE SEQUENCE}

The eruptive sequence interpreted to have formed the VNW pipe comprises two separate eruption cycles, each of which produced a comparable series of deposits. The facies associations (two from the first and three from the second eruption cycle) generally comprise a number of individual facies. These are described briefly below (see van Straaten et al., this volume, for more comprehensive, non-genetic facies descriptions) and the spatial relationships, textural and component characteristics are used to elucidate the fragmentation mechanisms and eruption dynamics of formation.

\section{Lowermost facies association (FA 1)}

The lowermost FA comprises two distinct volcanic facies: facies $1 \mathrm{a}$ and $1 \mathrm{~b}$. Facies $1 \mathrm{a}$ is found at the pipe wall (Fig. 1) and is bedded, country rock fragment (CRF) rich, broken olivine-rich, contains clastic (asharmoured) pyroclasts and the matrix is inferred to be ash-rich. This pipe-marginal facies most likely represents a record of the pipe excavation event. The characteristics of this facies suggest that the pipe excavation was highly explosive, causing pervasive shattering of olivine crystals and the production of abundant ash-sized kimberlitic material. Furthermore, these features are suggestive of magma-water interaction, since the products of phreatomagmatic eruptions are typically characterised by high

Figure 1: Cross section through the VNW pipe, see van Straaten et al. (this volume) for more information. abundances of fines, as well as the presence of clastic pyroclasts (Cas and Wright, 1987).

Facies $1 \mathrm{~b}$ forms the volumetrically dominant infill of the lower pipe. The CRF content is much lower compared to the underlying facies 1a, and notably, the abundance of broken olivines decreases away and upward from the pipe wall contact. This most likely indicates a gradual decrease in fragmentation intensity. In addition, the decrease in CRF abundance indicates that pipe enlargement came to an end. The dense and dark kimberlite that makes up this facies generally shows clastic textures such as broken olivines, fabric, patchy grain size variations, clast-supported areas and faint pyroclast outlines. The upper and central parts of this FA contain numerous intervals of coherent kimberlite with gradational contacts to the dense and dark clastic kimberlite. The above observations suggest that this entire facies is extrusive in origin. In addition, the presence of a fabric and multiple gradational transitions from coherent to clastic rocks suggests that they represent densely welded pyroclastic kimberlite formed by accumulation of spatter in a proximal, intracrater environment. Hence, we propose that these deposits are the result of relatively low energy

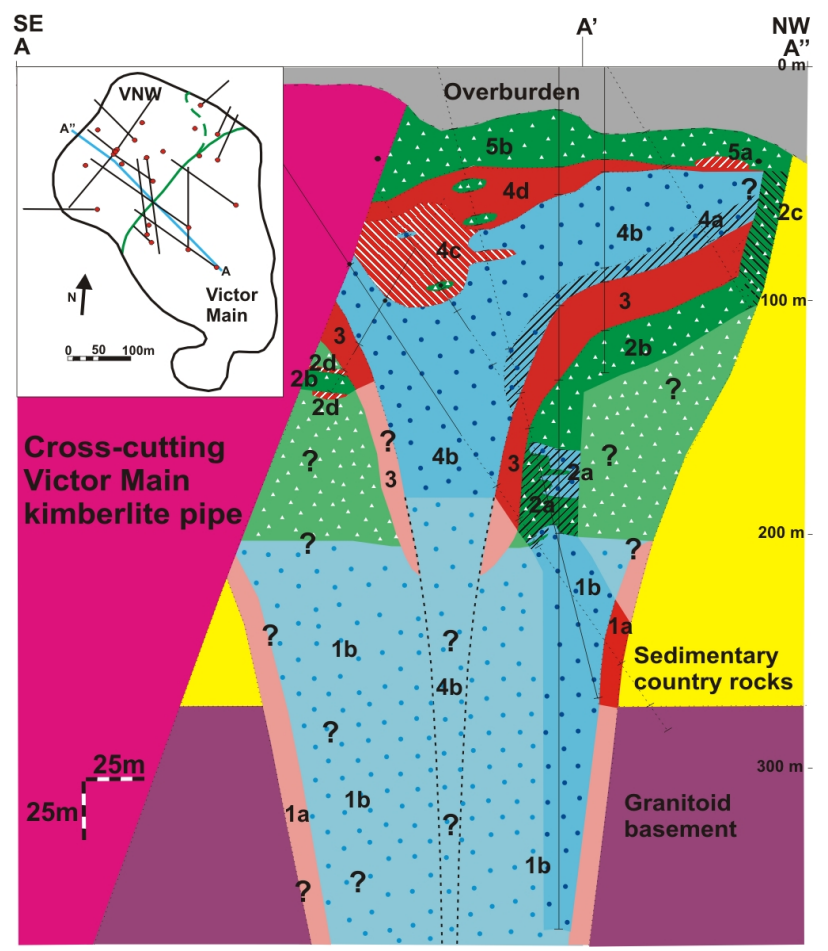


eruptions (e.g. fire fountaining) and welding of the proximal fall back deposits.

In summary, FA 1 documents a transition from highly explosive activity (facies 1a) to lower energy eruptions (upper and central parts of facies 1b).

\section{Lower-central facies association (FA 2)}

FA 2 comprises mainly a sedimentary country rock breccia (facies $2 \mathrm{~b}$ ) formed by pipe wall collapse at the end of the first eruption cycle. The underlying facies 2a, a variably CRF-rich kimberlite, is most likely representative of the transition from low-energy fire fountaining (facies 1b) to volcanic quiescence and the onset of pipe wall collapse (facies 2b). A mostly monomict country rock breccia (facies $2 \mathrm{c}$ ) is present at the pipe margins, and is inferred to have formed at the same time as facies 2 b. A small volume, bedded, wellsorted and closely packed resedimented volcaniclastic facies (2d) is present within, and above, the sedimentary country rock breccia (facies 2b), suggesting standing water was present in the open crater.

\section{Upper-central facies association (FA 3)}

FA 3 comprises a single facies of bedded CRF-rich volcaniclastic kimberlite. The start of FA 3 coincides with renewed volcanic activity within the VNW pipe, and the excavation of a nested, funnel-shaped depression within the larger VNW pipe fill. The presence of angular cognate lithic clasts indicates that the time gap between FA 1 and FA 3 was long enough to allow for lithification of the underlying deposits.

There is compelling evidence to suggest that the excavation of the nested crater, as well as the formation of FA 3, was caused by phreatomagmatism. The evidence includes the character and stratigraphic location of facies $2 d$, which suggest the presence of a crater lake prior to formation of the nested Figure 2: Schematic emplacement sequence for the VNW kimberlite pipe. See text for discussion.

\section{FA 3:}

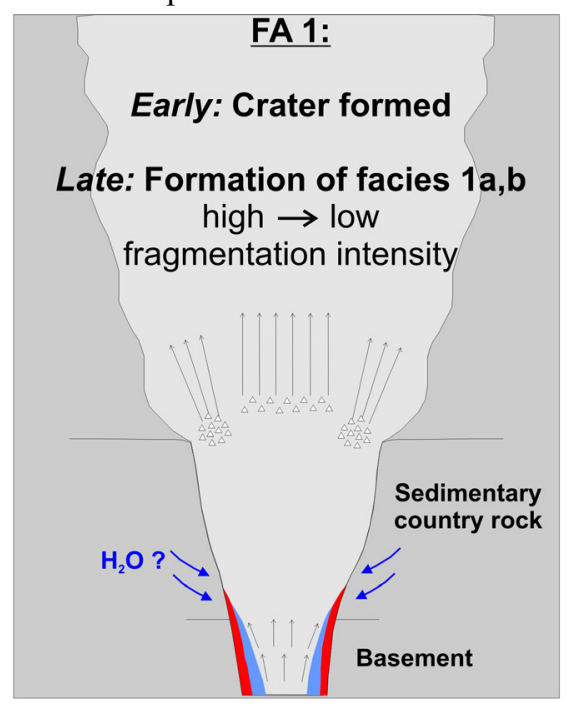

\section{FA 4:}

\section{Early: Nested crater formed}

\section{Late: Formation of facies 3 high fragmentation intensity}

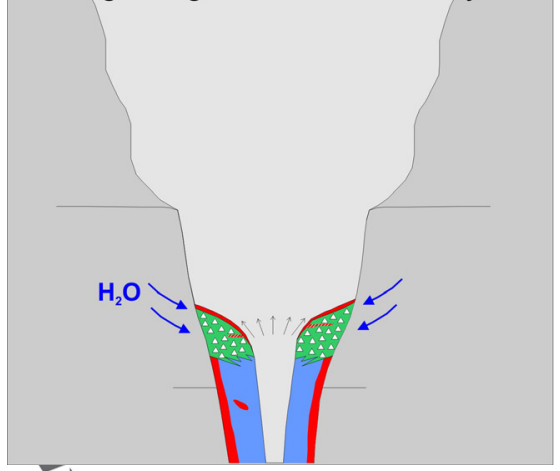

crater. Both ground and lake water would thus have been available for magma-water interaction. In addition, numerous textural observations within FA 3 suggest the plausibility of phreatomagmatic fragmentation. These features include the presence of variably vesicular juvenile pyroclasts (e.g. Cas and Wright, 1987), accretionary lapilli, variably CRF-rich bedded deposits, as well as high fragmentation intensities inferred from the high abundance of broken olivines, fines and small angular CRFs.

\section{Upper facies association (FA 4)}

The lower facies in FA 4 (facies $4 \mathrm{a} / \mathrm{b}$ ) has low CRFabundance, contains mostly intact olivine, and lacks accretionary lapilli and variably vesicular pyroclasts. Based on the dark, dense and clastic nature of this unit, together with the fact that certain intervals appear coherent in nature, it is suggested that these facies represent densely welded pyroclastic kimberlite formed by accumulation of spatter in a proximal, intra-crater environment. The transition from FA 3 to FA 4 is characterised by a marked decrease in explosivity. In many ways, facies $4 \mathrm{a} / \mathrm{b}$ are similar to facies $1 \mathrm{~b}$, and were likely formed by relatively low energy eruptions, such as fire fountaining.

Facies 4c (CRF-poor volcaniclastic kimberlite) most likely represents the non-welded pyroclastic 
equivalents of the enveloping and underlying welded facies $4 a / b$. Overlying facies $4 b$ and $4 c$ are variably CRF-rich volcaniclastic deposits (facies 4d) that contain minor country rock breccia intervals. This facies likely represents a gradual transition to the end of the last eruption and the onset of pipe wall collapse. These volcaniclastic deposits might, in part, originate from the collapse of tephra-ring deposits into the pipe.

\section{Uppermost facies association (FA 5)}

Facies 5a includes mud to sandstone intervals containing both kimberlitic and exotic (quartz grit, mud) material. This small volume facies comprises fining upward and cross-bedded sequences implying resedimentation into a local standing body of water. In addition, the presence of exotic material suggests that a stream cut through the tephra ring to supply foreign debris and water. This presents supporting evidence for the fact that some or all of facies $4 \mathrm{~d}$ is redistributed tephra ring material, thus marking the onset of tephra ring erosion and pipe wall instability.

Facies $5 \mathrm{~b}$ represents the true end of the second, and last, eruption phase at VNW, and the continuation and climax of pipe wall collapse. It comprises a thick package of sedimentary country rock breccia that blankets all previous deposits.

\section{POSSIBILITY OF PHREATOMAGMATISM}

In order to further explore the likelihood of a phreatomagmatic origin for the two volcanic facies (facies 1a, FA 3), we performed basic modelling of the magma-water interaction. For this exercise, we assumed that: (i.) a similar geohydrological situation existed during kimberlite emplacement (e.g. Norris, 1993); (ii.) estimated water flow rates for the mine site $\left(8.7 \cdot 10^{4} \mathrm{~m}^{3} /\right.$ day, HCI, 2004) are representative of past flow rates; (iii.) water to magma mass ratios varied from 0.3 (most efficient magma-water interaction) to 0.15 (less efficient interaction; Sheridan and Wohletz, 1981); (iv.) the total volume of excavated country rock material is distributed over the intra-crater and tephra ring deposits with either equal vol.\% CRF ( 30-35\%) in both deposits or double the vol.\% CRF $(\sim 70 \%)$ in the tephra ring deposits, and can be used to compute the total tephra volumes; (v.) the total volume of excavated country rock is represented by either the present day pipe volume (no erosion) or by adding a maximum of $300 \mathrm{~m}$ of eroded pipe material.

The modelling yields eruption durations of 1 week to 2 months for FA 3, comparable to those found in modern maar volcanoes (Cas and Wright, 1987), and suggest that this deposit is potentially phreatomagmatic in origin.

The modelling for facies 1a gives eruption durations ranging from 3 weeks to 2 years, which is significantly longer then the results for FA 3 . If the excavation of the VNW crater were driven by phreatomagmatism, this would have required progressive deepening of the pipe during a long eruptive phase. Another, equally valid, interpretation is that the initial crater excavation occurred in a much shorter time span, with dominantly magmatic (gas driven) fragmentation and magma flow rates that were too high to allow efficient magma-water interaction. Perhaps phreatomagmatism took place only during the waning stage of the eruption, when magma flow rates declined.

Of interest in this regard, is that the VNW crater extends at least $100 \mathrm{~m}$ below the basement Palaeozoic country rock interface. At these levels hydraulic conductivities are low, further decreasing the likelihood of phreatomagmatic pipe excavation.

\section{SUMMARY AND CONCLUSIONS}

This study builds on the detailed observation of the character and stratigraphy of intra-crater volcanic kimberlite deposits of the VNW pipe (van Straaten et al., this volume). Based on those data and the interpretations presented here, it is evident that the VNW pipe was formed by two separate but comparable eruption cycles (Fig. 2), each of which involved an early highly explosive crater excavation and volcaniclastic kimberlite deposition event (likely in part phreatomagmatic), and a subsequent episode of lower energy fire fountaining that formed welded deposits. In both cases the cessation of the eruptions was marked by deposition of minor resedimented kimberlite (formed in standing water), and major pipe wall collapse resulting in voluminous sedimentary country rock breccia deposits.

This study highlights the complex stratigraphy, diverse fragmentation intensities and variable eruption volumes possible in the formation of intra-crater volcanic kimberlite deposits. The presence of two kimberlite packages between pipe wall collapse breccias in Victor Northwest suggests that the eruptive volume in each case was insufficient to completely fill the crater. This implies that the style and volume of the eruptions at Victor Northwest were different to those involved in the emplacement of the cross-cutting Victor Main pipe, as the latter pipe is entirely and uniformly filled with volcaniclastic material. Numerous kimberlite localities worldwide show similar variations from low volume explosive eruptions leaving large open holes (e.g. Lac de Gras cluster) to higher volume explosive eruptions filling the entire pipe (e.g. Fort-à-la-Corne, Southern African-type kimberlites).

\section{REFERENCES}

Cas, R.A.F, and Wright, J.V. (1987). Volcanic successions. Chapman \& Hall, London, 528 pp.

Hydrologic Consultants Inc. (2004). Dewatering of the Victor diamond project. Report to SRK and De Beers Canada Inc., available on http://www.debeerscanada.com.

Norris, A.W. (1993). Hudson Platform - Geology. In: Stott, D.F. and Aitken, J.D. (ed.), Sedimentary cover of the craton in Canada. Geological Survey of Canada, Geology of Canada no. 5, p. 653-700.

Sheridan, M.F., and Wohletz, K.H. (1981). Hydrovolcanic explosions: the systematics of water-pyroclast equilibration. Science, Vol. 212, p.1387-1389.

van Straaten, B.I., Kopylova, M.G., Russell, J.K., Webb, K.J. and Scott Smith, B.H. (this volume). Stratigraphy of the intra-crater volcaniclastic deposits of the Victor Northwest kimberlite (Canada). 